\title{
EBOLA'S WOULD-BE REFUGEES: PERFORMING FEAR AND NAVIGATING ASYLUM DURING A PUBLIC HEALTH EMERGENCY
}

\section{Benjamin N. Lawrance}

Chronic and acute illnesses sit uncomfortably with asylum claiming and refugee mobilities. The story of a Sierra Leonean athlete who feared Ebola and sought refuge in the UK provides an opening to examine protection discourses that invoke fear, trauma, and crisis metaphors, to understand how asylum claims are performed, and how related petitions are adjudicated during Public Health Emergencies of International Concern. Ebola is revealed as a novel claim strategy, and thus a useful subject matter to investigate the shifting modalities of migrant agency, the unstable fabric of medical humanitarianism, and knowledge production in moments of exceptionality.

Keywords: Sierra Leone; United Kingdom; Ebola; Public Health Emergency of International Concern (PHEIC); Refugees/Asylum; trauma.

Running title: Ebola's would-be refugees

Media teaser: Is fear of Ebola grounds for refugee protection? Public immigration struggles highlight the performance of protection and role of knowledge production informing refugee determination. 
BENJAMIN N. LAWRANCE is Professor of History at the University of Arizona, author of Amistad's Orphans: An Atlantic Story of Children, Slavery, and Smuggling (2014), and coeditor of Citizenship in Question: Evidentiary Birthright and Statelessness (2017), with Jacqueline Stevens. Correspondence to: Benjamin Lawrance, Department of History, Cesar Chavez Hall, 1110 James E. Rogers Way, Tucson, AZ 85721. Email:

BENLAW@email.ARIZONA.edu 
On October 1, 2015 Jimmy Thoronka, Sierra Leone's top sprinter, received a second installment of devastating news. Only months after his immediate family had died from Ebola hemorrhagic fever, the United Kingdom Home Office (UKHO) not only rejected his humanitarian application to remain under Article Three of the European Convention of Human Rights, but also described his lawyers' claim that Thoronka was in a "chronic traumatised state" and incapable of caring for himself were he returned to Sierra Leone, as "clearly unfounded." His claim "did not meet the required thresholds within the immigration rules." Thoronka was told that he had no right to appeal until after returning to Sierra Leone. If he did not return voluntarily, the UKHO may arrest, detain, and forcibly remove him. Even the promise of a University of East London scholarship failed to sway the decision-makers. Thoronka, who had remained in Britain after the Commonwealth Games, was found destitute in London in summer 2014. After learning that Ebola had claimed eight family members, he absconded from his team's compound. He was arrested by immigration authorities, and then released into supervised care. Befriended by members of a local track club, he began training with a South African coach. Thoronka's lawyers provided an expert medical report asserting the sprinter was in a "chronic traumatised state" following his family's passing. After consulting its internal database of "Country of Origin Information" (COI) about Sierra Leone, the UKHO deemed his claim lacked merit on several grounds, among them, that trauma counseling existed in Sierra Leone.

After this negative decision, an expansive support network mobilized national and international news media to combat the UKHO's contention that suitable resources existed in Sierra Leone. Thoronka gave interviews, playing to the court of public opinion, a "court" that occasionally sways political leaders, though rarely the then Home Office Minister, Theresa May. "This is the worst, the lowest point," a tearful Thoronka told USA TODAY Sports. He blurred his fear of Ebola with anxieties about impending homelessness, poverty, and possible 
criminal prosecution for violating athletic regulations. Further, "Even when I lost my family I thought I could honor their memory with my career and my performances. Now I have nothing left” (Rogers 2015).

Ebola is a useful subject matter to investigate the shifting modalities of migrant agency (Redeker Hepner 2015), the unstable fabric of medical humanitarianism (Chung 2012; Abramowitz and Panter-Brick 2015), and the production of knowledge about public health emergencies. I examine several examples that, like Thoronka's, invoke fear of Ebola within broader protection claims. I explore the subsequent stages in the evolution of these claims with a view to understanding how claims are performed and decisions adjudicated pertaining to asylum and related protection claims submitted in the context of unfolding crises, particularly a Public Health Emergency of International Concern (PHEIC) such as Ebola. After outlining the methodology, I explain why Thoronka's case is instructive and situate Ebola within a discussion of illness, asylum law, and refugee protection. Three case studies suggest claimants and their advocates instrumentalized knowledge, fear and the vacuum of knowledge around Ebola, in order to perform (McKinnon 2009; Cox 2016) specific protection claims and appeals to humanitarianism. I subsequently discuss COI, its “crucial" (Gibb and Good 2013:92) adjudicatory role, and how it unfolds as bureaucratic practice during crises: what is COI, and how has it come to wield such power? In conclusion, I speculate about the next pandemic - future PHEICs or "future Ebolas"- to demonstrate the intrinsic role of crises in stimulating knowledge production. In emerging crises when biomedical knowledge is incomplete or when data are ambiguous, how do institutional networks, such as refugee determination apparatuses, marshal and obfuscate knowledge production?

THORONKA AND CONTEMPORARY ASYLUM-CLAIMING 
Thoronka's experience is unusual insofar as he gained extraordinary social, political, and media attention. A change.org petition attracted more than 70,000 signatures within a few weeks (see Figure 1). A GoFundMe website raised over $£ 32,000$ by October 7, 2015 (see Figure 2). Prior to the negative decision, dozens of news articles appeared in the UK and Sierra Leone. After the USA Today syndicated the story, thousands more appeared globally. But whereas he was surely not the only Sierra Leonean athlete affected by Ebola, he was the only "defector" (see Terretta 2015) alleging fear and trauma. In at least four respects, his case is instructive about the broader contemporary asylum-claiming landscape specifically and about South-North migration generally.

\section{[INSERT FIGURES 1 and 2 HERE]}

Thoronka's case is emblematic of a dramatic growth of public immigration struggles, which unfold when undocumented migrants contest their status in the public realm, via social media, such as blogs and twitter, and physical protest. Among the more famous precursors are the sans papiers and their French advocates in the 1980s and '90s (Noiriel 1991; Siméant 1998). Participants in these contemporary struggles, perhaps cognizant of the remarkable centralization of authority enabling a Home Office minister to personally adjudicate petitions, have attempted to marshal public opinion to pressure democratically elected

parliamentarians. In so doing, they seemingly short-circuit administrative and judicial processes. Exploits to facilitate the social "trending" of asylum claims constitute a high-risk strategy, according to Michael Collins at Right to Remain, a charity advising refugees. Public debate certainly does not guarantee success, as attested by Ugandan "lesbian" Brenda Namigadde (Lewis 2013; Bennett and Thomas 2013; Cox 2016) and Pakistani student Majid Ali (Devichand 2015).

Thoronka's case speaks to a possible overrepresentation of "medical humanitarian" issues (Chung 2012; Good et al 2014; Abramowitz, Marten and Panter-Brick 2014; 
Abramowitz and Panter-Brick 2015; Lawrance 2015). Approximately 25,000 new asylum claims are filed in the UK annually, but few are contested in the public sphere (Ticktin 2006). ${ }^{1}$ Only extraordinary stories hold public attention, even briefly, and the chronically ill, like transplant recipient Roseline Akhalu (Lawrance 2015) or the late Ghanaian cancer patient Ama Sumani (Jackson 2008; Lawrance 2012/3; Willen and Cook 2016) appeal to public sentiment. Indeed, James Dominic Smith observes that cancer is now "a major challenge for humanitarian health providers" and for those supporting asylum seekers (Smith 2014:e363). Sporting prowess frames another subset of such cases; the ordeals of the Cameroonian Olympians who "overstayed" in London (Terretta 2015) echo elements of Thoronka's story.

Asserting Ebola as a basis to contest deportation also underscores the conflation of medical humanitarianism, asylum, and refugee status with social mobilization and political expedience. In an interview with Guardian journalist Diane Taylor, entrepreneur Emma Sinclair suggested people "tweet" Secretary May with the \#KeepJimmyHere hashtag. Revealing a meagre knowledge of migration policy or asylum grounds, she asserted, I cannot bear the thought of having to... send him back to a country where he no longer has his family unit and where his training cannot be supported. Some of us in London have gladly become Jimmy's new adopted family and I would be devastated if he had to be uprooted again and I had to say goodbye to him — all the while knowing he is no burden on the state and indeed has the capacity to make the whole country proud. Jamaica and the US welcome African asylum seekers who are world-class athletes and we are keen to give him away. (Taylor 2015)

In Sinclair's convoluted rendition, Thoronka's "Ebola trauma" is displaced by an even greater British tragedy, the loss of a promising athlete. Thoronka's family may already 
be deceased; but deportation will surely kill his career. This rhetorical slippage-from Ebola as fear and jeopardy, via Ebola as trauma, to Ebola as deprivation of opportunityunderscores how asylum practice and migration policy collapse when national pride and public sentiment collide.

Fourth, and most important here, public struggles also point to a critical dimension of the new migration frontier propelled by increasing South-North mobility, and the bureaucratic apparatuses that collect, order, and produce knowledge germane to refugee determination particularly during crises. Country of Origin Information is "crucial in almost every asylum claim" (Gibb and Good 2013:292). Thoronka's assertions simply did not stack up, as far as the UKHO was concerned, when compared with available COI. Irrespective of whether or not he may have a "right" (Willen 2011) to mental health care, the UKHO identified "counseling," at least of a fashion deemed sufficient, to exist in Sierra Leone.

\section{METHODS}

This analysis is based upon 150 asylum applications, appeals documents, and related documentation (emails, phone consultations, and informal communications) of cases pending or submitted before immigration authorities in the UK and the United States from December 2013 to November 2015, of which approximately 15 percent reference acute medical conditions or related fears. I gained access to this documentation in my capacity as an international expert witness on issues pertaining to political violence, gender-based violence, and the provision of medical care in Sierra Leone, Guinea, Côte d'Ivoire, and Nigeria. Although this information was provided to me for non-research purposes in a non-academic context, I took the additional step of cloaking asylum applicants' identifying information in all contexts not already in the public domain, to assure confidentiality. 
While individually these cases may seem anecdotal, I approach the documentation using discourse analysis, with an emphasis on studying the use of key terms like "trauma", "Ebola," "fear," "risk," and "epidemic" in building support for protection. All originated with legal advocates representing persons seeking asylum from countries affected by the West Africa Ebola epidemic (Guinea and Sierra Leone) or a neighboring country (Côte d'Ivoire). My approach allowed for the repeated observation of the strategic deployment of textual and rhetorical arguments in legal contexts. Subsequently, I drew conclusions about informal norms operating in formal legal contexts, evidentiary strategies, and the public sphere as represented in social media, the internet, or newspapers and magazines.

I was not directly hired to consult on any cases examined here. However, the main limitations of this study are: (1) my data are based on an opportunistic sample of documents closely associated with my known areas of professional expertise; and, (2) because I did not serve as an expert for any case studies examined here, I was unable to identify an appropriate opportunity for follow-up interviews, informal, structured, or otherwise. Conversely, my familiarity with refugee law and asylum claims provided me with the perspective to add heuristic value to an analysis of asylum claiming and rejecting discourses. Informed with this perspective, terms such as "trauma" and "epidemic" are elaborated with respect to their legal performativity and not merely their social significance.

\section{ILLNESS, FEAR, AND THE PERFORMANCE OF EXCEPTIONAL PROTECTION}

Because illness sits uncomfortably with asylum claiming and refugee procedures, we need to recognize exactly what is at stake in Ebola-related protection claims. Illness and disease have been observed to inhabit an experimental toolkit for those with ambiguous legal status. Miriam Ticktin witnessed that in France, undocumented migrants "turn to physical injury or infection to claim" basic rights, to engage a humanitarian law that "gives people with serious 
illnesses the right to stay... and receive treatment" (Ticktin 2006:33). "Illness" operates as a “primary means" by which society's most vulnerable "end up trading in biological integrity for political recognition” (Ticktin 2006:33). Just as the medical humanitarian urgency embodied in Thoronka's narrative appears to grasp at "bare life" (Agamben 1988:133), so the asylum context remains deeply political; it operates within and gives rise to deeply unpalatable "political choices" or "options" (Ticktin 2006:35).

Juxtaposed with political choice and expedience, decisions about a "well-founded fear of being persecuted"- as required by the 1951 Refugee Convention and the 1967 Protocol that extended refuge globally_ - depend on hard facts and empirical data, what are known today as "Country of Origin Information" (COI) research about an applicant's origin country's history and prevailing situation (Khoser and Pinkerton 2002; Collier 2007; Flärd 2007; UNHCR 2011; Gibb and Good 2013). ${ }^{2}$ Although Ebola is not a "novel” disease (Wilkinson 2017), fear of Ebola as a distinct protection basis, even temporary, was certainly novel in 2014. As a novel claim, it was subject to intense scrutiny by refugee status determination (RSD) decision-makers; this was not an ad hoc practice. When RSD agents encounter seemingly "new" or "protean" (Lawrance et al 2015) persecutory concepts or entities — such as fear of witchcraft (Luongo 2015) or reprisal by Boko Haram (Lawrance 2016) - they consult government databases of country conditions or commission new COI research against which to scrutinize claimant narratives.

Before continuing, an overview of the legal contours of asylum claiming may be useful. When migrants (such as Thoronka), arrive in a host country (such as the UK), they have various opportunities to signal a need for protection. They may formally request assistance immediately, or they may seek the guidance of lawyers or volunteers after time in country. Regardless of the path, oral and written statements about the persecutory fear basis are required. Government agents — often in ministries of immigration, citizenship, or border 
enforcement—evaluate these and proffer decisions. The Refugee Convention and Protocol mandate that signatories (such as the UK) provide protection for those "who owing to a wellfounded fear of being persecuted for reasons of race, religion, nationality, membership of a particular social group or political opinion" find themselves outside their country, and "owing to such fear," are "unwilling to return to it."

The UKHO rejects the majority of applications as unfounded (Griffiths 2014), not credible (Sweeney 2009:701), or otherwise inadmissible. ${ }^{3}$ Most rejections are appealed to the First-tier Tribunal, part of the court system. (By comparison, in the US, the first instance judges are administrators within the Department of Justice.) Decisions from the first instance may be appealed by either party, but a majority are determined at the first instance or the immediate superior instance; in the UK, this is the Upper Tribunal. At each and every stage asylum-seekers have the opportunity to present evidence, including COI data; and each decision must reference COI and be consistent with applicable laws and regulations.

When those who drafted the Refugee Convention first conceived of refuge, discussion was shaped by the targeted prosecution, persecution, and mass killings by Nazi forces. Jews, Sinti, Jehovah's Witnesses, and others, unable to escape invading armies or denied entrance to countries where they may have survived, were murdered. The drafters created protected categories: nationality or citizenship (Nuremburg laws made Jews stateless); race or caste (Sinti and others were marked inferior); religion (Jehovah's Witnesses and others were persecuted); actual or imputed political opinion (Communists and others were imprisoned); and a fifth category, members of a "particular social group" (PSG).

The drafters provided little guidance about the meaning of this fifth category. PSG has been interpreted by some as "forward-looking" (Holzmann 2001), designed to safeguard the interests of yet-to-be-targeted victims. Others have suggested it was a subtle nod to homosexuals and other targets of totalitarian regimes, yet to garner wider socio-cultural 
acceptance (Henes 1994). Nations and international bodies have struggled to interpret PSG. The US experience is instructive: an early interpretative decision, Matter of Acosta (1985), reasoned it should be "construed in a manner consistent" with the other four terms, an approach known as ejusdem generis. The US Board of Immigration Appeals reasoned that as other categories describe a trait or characteristic that "is either beyond the power of an individual to change or is so fundamental to individual identity or conscience that it ought not be required to change," a PSG should therefore be marked by either immutable or fundamental characteristics. The Acosta framework has been adopted widely, in Canada, Australia, New Zealand and, importantly, in the UK. Subsequent jurisprudence further considered "social perception" and visibility. ${ }^{4}$

While Ebola's would-be refugees do not sit neatly in any of these five categories, it is possible to discern from Thoronka's narrative a tentative persecutory "nexus" (Redeker Hepner 2015). The medical humanitarian dimension is clear; but the risk of Ebola infection may only deliver what the UK calls "discretionary leave to remain" or "temporary protected status" in the US (Seghetti et al 2015:432; Mountz et al 2002). Further, Thoronka claimed fear of political retribution by government agents, a well-established refuge basis. He also described in interviews the "stigma" of being an Ebola survivor; stigma or social exclusion in various forms, such as those with HIV/AIDS, may meet the "social group" definition in exceptional instances (Margulies 1994), and in some respects Ebola and AIDS “occupy similar policy terrain" (Weiss 2015:5). Cobbled together, Thoronka's claim underscores how migrants, all too often "the ones most affected" (Ticktin 2005:349) by crisis-inducing exceptionality, strategize and perform their narratives.

By employing "crisis" metaphors (Mbembe and Roitman 1995) with reference to Ebola, asylum seekers appear cognizant of the benefits of strategic references to the vocabulary of crisis to "perform" (McKinnon 2009; Cox 2016) their trauma as a claim for 
refuge. From mid-2014 Ebola began to feature in West African refugee narratives and requests for expertise (see Lawrance and Ruffer 2015), albeit tentatively and inconsistently. Ebola fear was no sure path to protection for Thoronka: it was a highly risky argument to advance in 2014-15 partly because knowledge about the disease and its effects was expanding swiftly (Bolten and Shepler 2017; Abramowitz 2017). UKHO officials scrutinized Thoronka's claims against regular streams of new information emanating from Sierra Leonebased British embassy staff and Department for International Development personnel. Humanitarian logic "involves interpretation” (Ticktin 2006:36). Unlike cancer or other chronic conditions, however, because Ebola briefly resided within an PHEIC crisis framework of "abjection" (Nunes 2016) and instability, it also operated within an expanded terrain of exceptionality (Hofman and Au 2017:xix, 19).

In summary, asylum claims offer an unusual psychosocial viewpoint on popular perceptions about Ebola, the imagined experience on the ground, and legal imaginaries and motivations of migrant advocates. For many years prior to and during civil conflicts, citizens from Sierra Leone, Liberia, Guinea, and Côte d'Ivoire fled their domestic settings and sought asylum; their narratives became important repositories of data about regional conflict (Lawrance 2017a). And just as PSG claims have expanded to incorporate a broad spectrum of gender-based and sexuality-targeted violence (Lawrance 2017b), it is important to consider the possibility that Ebola-related claims may be part of a dynamic refugee jurisprudence, one that may yet stretch protection to include future PHEIC-related mobilities.

\section{PERFORMING EBOLA FEAR: THREE CASE STUDIES}

Ebola in West Africa swiftly reached a contagion "outbreak narrative" (Wald 2008) whereby an exotic "neglected tropical disease" (Honigsbaum 2017) morphed uncontrollably into an international "biosecurity threat" (Abramowitz 2017; Desclaux 2018). "Alarm and near 
panic" was a core social response to earlier Ebola outbreaks in Sudan, Congo, and Uganda (Kinsmen 2012; Ilunga Tschiswaka et al 2017). At the onset of the 2013-16 West African epidemic, fearful ideas spread word-of-mouth quickly, and social media (Basch et al 2015; Hossain et al 2016) and news featured prominently (du Bray 2012; Dionne and Seay 2015). Fear manifested in many ways to contribute to early rapid spread (Wilkinson and Leach 2014). Fear, rumor (Goguen and Bolten 2017:424), and stigma (Ludwig 2016) gave rise to a psychosocial support focus (Cheung 2015).

Fear and panic was not confined to Africa (Power 2014). Stories of Ebola-affected communities were translated globally (Biruk 2014). US citizens traveling abroad to and from Liberia, Guinea, and Sierra Leone were subject to graphic visual warnings; "near panic" (Bolten and Shepler 2017) reigned. Fear of Ebola, aided and abetted by news media, quickly entered an institutionalization phase, whereby hallowed agencies offered tailored expert warnings and guidance. The institutionalization of "fear remedy services" in North America is perhaps best represented by the "Managing your fear about Ebola" (see Figure 3) website of the American Psychological Association. ${ }^{5}$

\section{[INSERT FIGURE 3 HERE]}

Fear of Ebola, embedded within wider "structural violence" (Ferme 1998; Farmer 2004; Wilkinson and Leach 2014), comprised many anxieties and concerns. Local inhabitants feared the unknown, they feared death and dying painfully, they feared the sight of blood or other bodily fluids; and many feared abandonment and isolation. Fear is a surely a rational subjective response to danger; but fear was perhaps exacerbated by "chronic conditions" of insecurity and the historical "social memory" (Green 1994) of civil war and post-war instability. Further, unlike fear born of social violence or political upheaval, anxieties about Ebola were often unanchored, or, alternatively anchored by the unknown or "not-known" (Bolten and Shelper 2017:359). Ebola fears "hamper[ed]" (Schroven 2014) and incapacitated 
local and global responses, but they also "motivate[d]" (Leach 2010) responders. The initially somewhat sparse biomedical knowledge on the ground about how and why the disease was spreading so rapidly may also have caused hesitation on the part of UKHO adjudicators.

Thoronka, and other would-be Ebola refugees described below, perhaps embraced this knowledge instability to frame their claims and highlight current risk and future jeopardy. Asylum claims invoking Ebola, however, are distinct from other PSG claims, because as the case studies demonstrate, Ebola is "tagged" onto pending or previously lodged claims, as an additional risk factor. In Thoronka's claim, Ebola was both a cause of his "chronic" mental state and the asylum "nexus" (Redeker Hepner 2015). Three further examples, in the form of requests for expert evidence assistance, illustrate how Ebola fears or jeopardies may be framed as additional or ancillary grounds for protection. And partly because some experts, myself included, routinely received expertise requests about many areas beyond their expertise (Berger et al 2015), the discourse in these case studies referencing Ebola is often speculative, hypothetical, conjectural, even optimistic.

\section{Case Studies}

In the first case (A), a UK lawyer representing a client from Guinea, in October 2014 tied Ebola danger to current travel warnings targeting foreigners. She wrote to me by email: I hope you don't mind me contacting you directly_-I was directed towards your details on the country expert list on the Fahamu website. I'm currently supporting an asylum seeker who is trying to find a country expert to verify certain elements of her claim as noted below:

- Authenticating Guinean death certificates 
- Likelihood of 'levirat' in Malinké community (forced re-

marriage to deceased husband's brother)

- Likelihood of F[emale] G[enital] M[utilation] upon

marriage to husband's brother?

- Changed C[ountry of] O[rigin] I[nformation] since asylum interview. COI for Guinea in Oct 2014 advises against all travel to the area (https://www.gov.uk/foreign-traveladvice/guinea). In May 2014 interview the interviewer noted "If that [high chance of catching ebola] was the case the $\mathrm{W}$ [orld] $\mathrm{H}$ [ealth] $\mathrm{O}$ [rganization] would not advise people to travel to Guinea".

Would you be able to help verify any of the above elements? Do let me know if I can provide any further information.

Within this narrative, Ebola was framed as changed "country conditions" that may be "verified." Ebola was juxtaposed against unrelated cultural practices such as "levirate" and "FGM," which have been found to meet PSG designation under certain circumstances. The fearful "catching ebola (sic)" instantiates a "traveler's" risk, and the deported failed asylumseeker is recast as a traveler-at-risk, no longer a national returning home.

In a second case (B) from Côte d'Ivoire, a lawyer speculated about the difficulties facing a client being returned to Abidjan. The email from October 2014 read:

I am acting for an Ivorian lady in her asylum case in the United Kingdom. She has claimed asylum on the basis that she fears being subjected to FGM. Her father and her husband were from the Malinke tribe, who she asserts practice FGM. In their reasons for refusal letter, the Home Office have (sic) argued that her claim is 
not credible and that even if it were, she could internally relocate to Abidjan and there is no way her family members could locate her there. There was country guidance on the Ivory Coast in the UK... which held in general terms that internal relocation to the capital was feasible for lone women. Since that case was determined, there was considerable political unrest in the Ivory Coast and more recently, the outbreak of the ebola virus in West Africa, so I am wondering if the position has changed with regards to internal relocation. What I require is an expert report dealing with the credibility issues (mostly dealing with plausibility) and the issue of internal relocation within the Ivory Coast.

I have already observed that risk of FGM (or "genital cutting") is oftentimes a protected PSG, but the UKHO rejected this woman's fear. Ebola is thus framed within wider structural patterns of instability and insecurity. Generalized violence and instability was narrowed to be particularly terrifying to "lone women." Ebola had not reached Côte d'Ivoire; and it never did. Instead Ebola was contextualized as contributing to other forms of frightful "unrest" as an "outbreak," incapacitating mobility.

In a third case (C), from August 2015, a lawyer described a client from Sierra Leone with HIV. She explained:

I am looking to commission an expert report for one of my clients who is making an application to remain in the UK on the basis of his marriage. Both my client and his wife, who is settled in the UK, are suffering from HIV. My client is currently taking [anti]retroviral medication[,] which is keeping his HIV suppressed. His wife has not commenced any treatment of the illness but is 
being monitored. The position of the Home Office in the UK is that they could return to Sierra Leone because treatment is available. My client's position is that they are unwilling to return because of the stigma that they would be subjected to if it became known that they have HIV. Additionally they are concerned about the level of treatment that would be available, particularly as Sierra Leone continues to fight the Ebola epidemic. I would like to find out if you could assist with a report in relation to the issue of stigma in the community as well as current availability of treatment for HIV in Sierra Leone. I would want to rely on some updated evidence in relation to support my client's claim that it would not be reasonable for them to return.

In this example, the individual had already marshalled a medical humanitarian defense against removal, but his lawyer sought to fortify the issue of stigma. Since the landmark 2008 case of $N . v$ United Kingdom concerning the removal of a Ugandan suffering AIDS, claims alleging the absence of medical treatment constitutes "inhuman" or "degrading" treatment face a very high threshold. ${ }^{6}$ In some isolated cases, HIV/AIDS sufferers have won protection (e.g. Stempniak 1999; Ford 2005), but in the UK individuals face difficult odds (Ingram 2008). Ebola is here, amplified by stigma (Ludwig 2016), introduced as an additional obstacle to the Sierra Leonean state's capacity to provide care.

In each of these cases Ebola is ambiguous, unstable, and multivalent. Ebola as a specific risk is hard to pin down. Ebola asylum claims highlight conditional, continuing, hypothetical risks, the existence of which are predicated on several conditions, such as documented "ethnic" practices, known "country conditions," and travel warnings geared at travelers from the Global North. In other contexts, asylum-seekers have been found to invoke 
conditional, contingent, and hypothetical risk and jeopardy by employing terms that resonate with relatively newly established gender rights (Lawrance 2017a). Echoing this contingency, Ebola fear, risk, and jeopardy appear to be tentatively envisioned or imagined by lawyers and/or their clients; perhaps Ebola's arrival even motivated the retooling of claims.

\section{PLAUSIBILITY, CREDIBILITY, AND COUNTRY OF ORIGIN INFORMATION}

Thoronka's claim was rejected partly because of the refutation of the contention that psychosocial services were unavailable in Sierra Leone. As his rejection letter is not part of the public record, the actual COI consulted is unknown; but trauma counseling "availability" researched on the internet using Google and the keywords "psychological counseling in Sierra Leone" produced multiple hits including a TIME article (Gidda 2014). NGOs affirmed counseling services existed, although of various capacities (Watson-Stryker 2016); and this type of data constitute what the UNHCR, COI researchers, and RSD decision-makers routinely refer to as "publically available objective evidence" (Lawrance 2015:236). Although one informant described in stark terms "the collapse of the healthcare system" and the "flagrant lack of mental care" in Sierra Leone (Buchanan 2014), the UKHO is under no obligation to weigh inconsistent COI. It selects information solely to buttress decisions. ${ }^{7}$

Space limitations prevent me debating this dubious "objective data" framework (although this is very much needed), but the plausibility of Thoronka's claims - and thus (and problematically) the credibility of the claimant himself - were undercut by verifiable socalled "objective" evidence. Assessing the plausibility of claims and the credibility of claimants is an important rhetorical strategy of decision-makers. It merits scholarly attention because it reveals the unanchored dimensions of a claimant's legal predicament insofar as it reveals the intrinsic role of information collection, assemblage, storage, and access. How can a claimant respond to a critique, or a rejection, if some or all of the evidence is withheld? 
Because refugee law draws on criminal (Byrne 2005:180) and civil law, and is not simply human rights practice or international humanitarian law, problems like this are preponderant. The measurement of refugee consistency and plausibility can never be an exact science, and "how much" (Sweeney 2009) of one or the other depends on many factors. RSD operates within a "discretionary" (Zeleznikow 2000) legal domain, the "fundamentally subjective" (Hathaway 1990:168) caprice of which unfolds in policy, procedure, "highly malleable conceptual" standards (Hathaway 1990:169), and practices, many of which are the subject of legal challenges, judicial review, international mandates, and public criticism.

Michael Kagan (2003) discerns the central elements of credibility as separated into "positive" and "negative" factors that are accorded probative weight in adjudication. The positive factors consist of detail, specificity, consistency, furnishing all facts early in the proceedings, and general plausibility. The negative factors are vagueness, contradiction, delayed revelation of details and facts, and general implausibility. These powerful probative criteria, however, may not be divorced from the multiplicity of production contexts. As Rose Byrne observes, asylum seekers "must deliver their testimony credibly, and must be found credible in differing contexts" (2005:179).

Credibility assessment speaks to a central tension embodied in asylum seekers, insofar as they are thrust between the imagined and idealized legal protections and national realities and arbitrariness of domestic immigration control. Credibility draws attention to the “intensely narrative mode” (Millbank 2009:1) of RSD's adjudicatory power and the central importance of communication (Doornbos 2005). Robert Thomas (2006:80) explains the central tension thus: on the one hand, recognizing "genuine claimants is to fulfil the humanitarian objectives of the convention and protect fundamental human rights." On the other hand, "the decision-maker" is also "concerned to ensure that non-genuine applicants are refused in order to maintain ordinary immigration control.” But as Kagan has observed, 
assessments of credibility_ “often the single most important step" in adjudication—are "frequently based on personal judgment that is inconsistent from one adjudicator to the next" (2002:367, 378).

While those unfamiliar with expert testimony may cast a suspicious eye at news media, such as TIME magazine, cited as "evidence," my analysis is informed by extensive interactions with the UKHO, and my experience reviewing more than a hundred "Reasons for Refusal Letters," the informal name given to the first decision. Adjudicators are not legally required to weight individual information elements, nor to seek COI that supports a counterposition (Good 2007). The UKHO provides limited guidance about using COI, and generally only requires a narrative to be evaluated against evidence "in the round" (Thomas 2008:516, 519). The 2015 iteration of its “Asylum Policy Instruction" observes,

The question to be asked is whether, taken in the round, the caseworker accepts what he or she has been told and the other evidence provided. In practice, if the claimant provides evidence that, when considered in the round, indicates that the fact is 'reasonably likely', it can be accepted. A caseworker does not need to be 'certain', 'convinced', or even 'satisfied' of the truth of the account - that sets too high a standard of proof. It is enough that it can be 'accepted'. (UKHO 2015; my emphasis)

Weighting evidence for relevance and bias, scientific and scholarly merit, is beyond its remit. This begs the question: what of our three case studies? How might they have fared under this evidentiary regime?

\section{COI and Ebola}


For the purpose of RSD, external consistency necessitates that adjudicators evaluate new claims against COI (Good 2015). Adjudicators must decide not only whether an uncorroborated story appears internally credible, but also that it is externally consistent with available COI (Weston 1998; UKBA n.d. I[4.3). Unprecedented or unusual claims are subject to additional scrutiny and they provoke enquiries from RSD officers or tribunal judges to COI directorates. Knowledge about Ebola expanded rapidly during the epidemic (Abramowitz 2017; Bolten and Shepler 2017; Goguen and Bolten 2017). PHEIC-like crises spark urgent data collection, perhaps contributing to uneven and differing claim assessments. COI represents a uniquely national, applied iteration of what has been called "global knowledge" (e.g. Mahajan 2008; Rothstein 2009; Keim, Çelik, Ersche and Wöhner 2012). In response to the expanding RSD evidentiary burden, over several decades, national COI directorates, independent research centers, NGOs, and for-profit companies, operating under a spectrum of mandates, self-regulation, national policies and ideologies have proliferated in the Global North. COI research operations consist of research "networks" (Riles 2000) employed by government ministries, professional contractors, court clerks, on-the-ground technicians or embassy staff, or freelance contracted academic professionals. Each national COI production site is a dynamic "science-lay hybrid assemblage" (Delgado 2010:564) of global knowledge, wherein refugee subjectivities and evidential objectivities coalesce on the path toward decision-making.

COI about Ebola comprises publicly accessible information. COI researchers (as opposed to decision-makers) may not access concealed or secret knowledge; indeed, much of their information is generated by experts, such as scientists and fieldworkers on the ground or in laboratories throughout the globe. Data on medical provision in Sierra Leone (Case C) are easily accessible. The Sierra Leone Ministry of Health and Sanitation publishes a "National Essential Medicines List of Sierra Leone," and a "Basic Package of Essential Health Services 
for Sierra Leone.” Such documents may constitute evidence about medical provision sufficiency or insufficiency. COI about political instability in Côte d'Ivoire (Case B) is available in the form of NGO reports, such as Human Rights Watch and Amnesty International, stored in the UN Refworld.org database. And US Department of State (USDOS) Human Rights Reports provides insight into social practices and cultural attitudes in Guinea (Case A), such as levirate and FGM/C; indeed, USDOS reports are quoted at length in COI databases the world over. COI researchers assemble, collate, order, and annotate this type of information with respect to source, authenticity, reliability, and verifiability; they produce comprehensive national (i.e. UKHO), international (Refworld.org) or - the case of the European Asylum Support Office in Malta—supranational (accessible to EU-member state ministries only) reports. And decision-makers routinely turn to COI research databases — national, international, and supranational - to access this knowledge and cite it alongside decisions.

While Ebola may appear "new" to COI researchers, as with all novel claims knowledge production is harnessed to and funneled through existing COI apparatuses. COI apparatuses appear to have emerged domestically and unevenly from international law. Contemporary asylum practices, such as COI, operate within the national iterations of the convention and protocol. The UNHCR continues to play a role in setting standards but whether HIV/AIDS stigma or Ebola trauma rise to the level of PSG persecution is decided by the UKHO, informed by British COI databases, comprised of information collected by British COI researchers or contractors.

An empiricist vision may reside at the heart of COI methodology, but its compilation, indexing, databasing, storage, and ultimately its implementation is infused with national anxieties and domestic exigencies (see Gibney 2008; de Genova and Peutz 2010; Kanstroom 2012). Whereas each claim is considered on its merits, decisions based on COI may become 
“precedent-setting" (Good 2015). Attempts to investigate and prove aspects of one particular case may subsequently become benchmarks (Kassindja 1998; Musalo 1998; Piot 2007). Embedded within refugee narratives, and their successive iterations in rulings, judgments, COI information, appeals and precedents, are analytical categories, constructed identities, and personal narratives of fear, trauma, and jeopardy. And even though Ebola knowledge production was a World Health Organization-driven global project from circa July 2014, albeit "underwhelming and uninspiring" (Youde 2015:11), COI informing Ebola-related protection claims, such as those described above, were transmuted nationally. COI operates within the constraints imposed by national legal processes as an institutional setting that "reproduces" state power (Stevens 1999).

With these considerations, it merits returning to the kernel of the original claim with which we began this analysis: might one prevail with fear of Ebola as a well-founded basis for protection? Thoronka's experience suggests it is unlikely that COI could be marshalled to support anything beyond temporary protection (Seghetti et al 2015:432). COI highlights the “hermeneutics of suspicion” (Ricœur 1965; Gadamer 1984; Stewart 1989; Kessler 2005) that characterize refugee proceedings wherein the importance of empirical research in establishing claimant credibility grows inexorably (UNHCR 2013; CREDO 2013). Claims and counterclaims must be anchored by objective data, publically sourced information, and arguments substantiated by scholarly evidence, all within an increasingly technologized adjudicatory context (Lawrance and Ruffer 2015; Good 2015). Decision-makers often assume a degree of "refugee deceit" (Kibreab 2004); and "floodgates" anxieties (Papastergiadis 2005) inform decision-making around novel or protean claims. But regardless of the biases that may or may not have influenced individual decision-makers, in the view of the UKHO, Ebola-related claims in the vein of Thoronka's were simply not well-founded. 
If we turn to consider under what conditions those fearful of Ebola may be considered a "particular social group," the data seem more equivocal. Fear of Ebola may shape a refugee claim by diminishing the capacity for safe internal relocation (Case A), but this is not a PSG. The ongoing Ebola epidemic may engage humanitarian protection because medical and psychological healthcare services have deteriorated severely (Case C); depending on the nature of the illness, this may generate a PSG claim. The presence of Ebola may contribute to a climate of instability rendering it unsafe to return someone whose asylum claim has otherwise failed (Case B); failed asylum claimants may be deemed a PSG under particular circumstances, such as acute mental illness (McColl et al 2008). And an individual's familial experience of, or death from, Ebola may contribute to stigma (Ludwig 2016), rendering it difficult for social reintegration. Thoronka's claim was perhaps not entirely without merit; it simply failed the UKHO's various tests.

\section{FUTURE PHEIC ASYLUM CLAIMS}

The massive public relations operation behind Thoronka notwithstanding, there was little appetite in the UK or elsewhere for granting anything more than temporary protection to those who feared Ebola in 2014-15. Nonetheless, in further research it may be instructive to consider some of the dimensions of possible future PHEIC-related claims. Ebola motivates (Leach 2010) in complex ways, and as previous seemingly new forms of claim suggest, refugees embrace novelty as part of a strategic performative engagement with the global RSD enterprise.

What is it about a PHEIC-designation that may give rise to a protection claim? The examples above point to the type of issues that decision-makers may have to consider in future claims citing fear of Ebola, and how knowledge production during an PHEIC may shape outcomes. Each of the aspects the case studies highlight may become the foundation 
for a protection claim for a migrant already abroad. Furthermore, each may provide the basis for someone to flee and make a new claim.

Exceptionality is also worthy of further study. References to Ebola direct our attention to how asylum seekers perform trauma as refugee narrative. But reference to Ebola fear or trauma is a risky approach. Each claim will be interrogated via the lens of COI, a global knowledge program to establish credibility, but also a research praxis engaging the "hermeneutics of suspicion" that exceptionalizes the global refugee experience. 


\section{ACKNOWLEDGMENTS}

Research was undertaken at the Rochester Institute of Technology in 2013-15. An early version was presented at a conference entitled "Beyond Ebola: knowledge production and the limitations of translation," October 2015, at the Max-Planck-Institut für ethnologische forschung, Halle (Saale), Germany. Thanks are due to Sharon Abramowitz, Cat Bolton, Anita Schroven, Charlie Piot, Rose Marie Beck, and the anonymous reviewers.

\section{FUNDING}

The research conducted for this article was partly supported by the Max-Planck-Institut für ethnologische forschung, Halle (Saale), Germany. 


\section{REFERENCES}

Abramowitz, S.

2017 Epidemics (especially Ebola). Annual Review of Anthropology 46:421-445.

Abramowitz, S., M. Marten and C. Panter-Brick

2014 Medical humanitarianism: Anthropologists speak out on policy and practice.

Medical Anthropological Quarterly 29(1):1-23.

Abramowitz, S., and C. Panter-Brick, eds.

2015 Medical Humanitarianism: Ethnographies of Practice. Philadelphia, PA:

University of Pennsylvania Press.

Agamben, G.

1998 Homo Sacer: Sovereign Power and Bare Life. Daniel Heller-Roazen, trans.

Stanford, CA: Stanford University Press.

Babo, A.

2017 Ivoirité and citizenship in Ivory Coast: The controversial policy of authenticité. In Citizenship in Question: Evidentiary Birthright and Statelessness. B.N. Lawrance and J. Stevens, eds. Pp. 200-216. Durham, NC: Duke University Press.

Basch, C.H., C.E. Basch, K.V. Ruggles, and R. Hammond.

2015 Coverage of the Ebola virus disease epidemic on YouTube. Disaster Medicine and Public Health Preparedness 9(5):531-35.

Bennett, C. and Thomas F.

2013 Seeking asylum in the UK: Lesbian perspectives. Forced Migration Review 42:25-28.

Berger, I., T. Redeker Hepner, B. N. Lawrance, J. Tague, and M. Terretta, eds.

2015 African Asylum at a Crossroads: Activism, Expert Testimony, and Refugee Rights. Athens, OH: Ohio University Press. 
Biruk, C.

2014 Ebola and emergency anthropology: The view from the 'global health slot'. http://somatosphere.net/2014/10/ebola-and-emergency-anthropology-the-viewfrom-the-global-health-slot.html.

Blinder, S.

2016 Briefing: Migration to the UK: Asylum. July 6 Update. Migration Observatory briefing, University of Oxford. Oxford. UK: COMPAS.

Bolten, C. and S. Shepler

2017 Producing Ebola: Creating knowledge in and about an epidemic. Anthropological Quarterly 90(2):349-368.

Buchanan, E.

2014 The Ebola death councillors offering therapy to stem trauma in Sierra Leone. International Business Times. December 12. [http://www.ibtimes.co.uk/eboladeath-councillors-offering-therapy-stem-trauma-sierra-leone-1479273]

Byrne, R.

2005 Credibility in changing contexts: international justice and international protection. In Proof, Evidentiary Assessment and Credibility in Asylum Procedures. G. Noll, ed. Pp. 179-196. Leiden, The Netherlands: Martinus Nijhof.

Cheung, E.Y.L.

2015 An outbreak of fear, rumours and stigma: psychosocial support for the Ebola Virus Disease outbreak in West Africa. Intervention 13(1):70-76

Chung, R.

2012. A theoretical framework for a comprehensive approach to medical humanitarianism. Public Health Ethics 5(1): 49-55.

Collier, B. 
2007 Country of Origin Information and Women: Researching gender and persecution in the context of asylum and human rights claims. London: AsylumAID.

Cox, E.

2016 Concealment, revelation, and masquerade in Europe's asylum apparatus: Intimate life at the border. Lateral 5(2).

CREDO

2013 Hungarian Helsinki Committee, Credibility Assessment in Asylum Procedures A Multidisciplinary Training Manual, Volume 1. Budapest: Hungarian Helsinki Committee.

de Genova, N. and N. Peutz, eds.

2010 The Deportation Regime: Sovereignty, Space and the Freedom of Movement. Durham, NC: Duke University Press.

Delgado Alemán, A.

2010 Activist trust: the diffusion of green expertise in a Brazilian landscape. Public Understanding of Science 19(5):562-77.

Desclaux, A.

2018 Une guérison d'ampleur nationale. Le cas de maladie à virus Ebola au Sénégal. In Guérir en Afrique, Promesses et Transformations : Anthropologie Comparée, A Desclaux, A. Diarra, eds. Paris: l'Harmattan. In press.

Devichand, M.

2015 Why one failed asylum seeker trended - while many others do not. BBC Trending, June 13, [http://www.bbc.co.uk/news/blogs-trending-33114685]

Dionne, K.Y. and L. Seay

2015 Perceptions about Ebola in America: Othering and the role of knowledge about Africa. PS: Political Science \& Politics 48(1):6-7. 
Doornbos, C.

2005 On being heard in asylum cases: Evidentiary assessment through asylum interviews. In Proof, Evidentiary Assessment and Credibility in Asylum Procedures. G. Noll, ed. Pp. 103-122. Leiden, The Netherlands: Martinus Nijhof. du Bray, M. V.

2012 What American media tell us about infectious disease. Honors Thesis in Anthropology, Whitman College.

Farmer, P.

2004 An anthropology of structural violence. Current Anthropology 45: 305-17.

Ferme, M.

1998 The violence of numbers: Consensus, competition, and the negotiation of disputes in Sierra Leone. Cahiers d'Études Africaines 38(150/152):555-580.

Flärd, H.

2007 The Use, Misuse and Non-use of Country of Origin Information in the Swedish Asylum Process. Stockholm, Sweden: Swedish Refugee Advice Centre.

Ford, L.L.

2005 HIV afflicted Haitians: New hope when seeking asylum. The University of Miami Inter-American Law Review 36(2/3):293-315.

Gadamer, H.-G.

1984 The hermeneutics of suspicion. In Hermeneutics: Questions and Prospects. G. Shapiro and A. Sica, eds. Pp. 54-65. Amherst, MA: University of Massachusetts Press.

Gibb, R. and A. Good 
2013 Do the facts speak for themselves? Country of origin information in French and British refugee status determination procedures. International Journal of Refugee Law 25(2):291-322.

Gibney, M.

2008 Asylum and the expansion of deportation in the United Kingdom. Government and Opposition 43(2):146-167.

Gidda, M.

2014 The psychological toll of Ebola in Sierra Leone. TIME, July 31.

[http://time.com/3063906/the-psychological-toll-of-ebola-in-sierra-leone/]

Goguen, A. and C. Bolten

2017 Ebola through a glass, darkly: Ways of knowing the state and each other. Anthropological Quarterly 90(2):423-449.

Good, A.

2015 Anthropological evidence and 'country of origin information' in British asylum courts. In Adjudicating Refugee and Asylum Status. B.N. Lawrance and G. Ruffer, eds. Pp. 122-44. Cambridge, UK: Cambridge University Press.

Good, B. J., M-J. DelVecchio Good, S Abramowitz, A. Kleinman and C. Panter-Brick.

2014 Medical humanitarianism: Research insights in a changing field of practice. Social Science \& Medicine 120(4): 311-316.

Green, L.

1994 Fear as a way of life. Cultural Anthropology 9(2):227-256.

Griffiths, M.

2014 'Who is who now?' Truth, trust and identification in the British asylum and immigration detention system. PhD dissertation. University of Oxford.

Hathaway, J.C. 
1990 A reconsideration of the underlying premise of refugee law. Harvard International Law Journal 31(1):129-184.

Henes, B.F.

1994 The origin and consequences of recognizing homosexuals as a particular social group for refugee purposes. Temple International and Comparative Law Journal 8(2):377-402.

Hofman, M. and S. Au, eds.

2017 The Politics of Fear: Médecins sans Frontières and the West African Ebola Epidemic. Oxford, UK: Oxford University Press.

Holzmann, R.

2001 Risk and Vulnerability: The Forward Looking Role of Social Protection in a Globalizing World. Washington DC: World Bank.

Honigsbaum, M.

2017 Between securitisation and neglect: Managing Ebola at the borders of global health. Medical History 61(2):270-94.

Hossain, L., D. Kam, F. Kong, R.T. Wigand, and T. Bossomaier.

2016 Social media in Ebola outbreak. Epidemiology and Infection 144(10):2136-43.

Ilunga Tshiswaka D., G.L. Whembolua, and D.F. Conserve.

2017 A qualitative analysis of newspaper response to the Ebola outbreak in Central Africa. Africology: The Journal of Pan African Studies 10(1):224-239.

Ingram, A.

2008 Domopolitics and disease: HIV/AIDS, immigration, and asylum in the UK.

Environment and Planning D: Society and Space 26(5):875-894.

Jackson, G. 
2008 Ama Sumani: avoidable death of a deportee. International Journal of Clinical Practice 62(6):843-843.

Kagan, M.

2006 The beleaguered gatekeeper: Protection challenges posed by UNHCR refugee status determination. International Journal of Refugee Law 18(1):1-29.

Kanstroom, D.

2012 Aftermath: Deportation Law and the New American Diaspora. New York: Oxford University Press.

Kassindja, F.

1998 Do They Hear You When You Cry? New York: Delacorte Press.

Keim, W., E. Çelik, C. Ersche and V. Wöhner, eds.

2012 Global Knowledge Production in the Social Sciences: Made in Circulation. Farnham, UK: Ashgate.

Kessler, A. D.

2005 Our inquisitorial tradition: Equity procedure, due process, and the search for an alternative to the adversarial. Cornell Law Review 90:1181-1275.

Kibreab, G.

2005 Pulling the wool over the eyes of the strangers: Refugee deceit and trickery in institutionalized settings. Journal of Refugee Studies 17(1):1-26.

Kinsmen, J.

2012 'A time of fear': local, national, and international responses to a large Ebola outbreak in Uganda. Globalization and Health 8:15.

Khalid, K. and C. Pinkerton 
2002 The social networks of asylum seekers and the dissemination of information about countries of asylum. United Kingdom Home Office Migration Research Unit, and University College London.

Lawrance, B.N.

2012/3 Humanitarian claims and expert testimonies: Contestation over health care for Ghanaian migrants in the United Kingdom. Ghana Studies 15-16:251-286.

2015 From 'health tourism' to 'atrocious barbarism': Contextualizing African migrant choice, expertise, and medical humanitarian practice. In Adjudicating Refugee and Asylum Status. B.N. Lawrance and G. Ruffer, eds. Pp. 221-244. Cambridge, UK: Cambridge University Press.

2016 Boko Haram, refugee mimesis, and the archive of contemporary gender-based violence. Radical History Review 126:159-170.

2017a Historicizing as a legal trope of jeopardy in asylum narratives and expert testimony of gendered violence. In Politics and Policies in Upper Guinea Coast Societies: Change and Continuity. J. Knörr, W.P. Murphy, A.-S. Helger, and C.K. Højbjerg, eds. Pp.145-168. New York: Palgrave.

2017b Asylum and the 'forced marriage' paradox: Petitions, translation, and courts as institutional perpetrators of gender violence. In Modern Slavery and Global Change. J. Quirk and A. Bunting, eds. Pp. 97-125. Vancouver, Canada: University of British Columbia Press. 
Lawrance, B. N., I. Berger, T. Hepner Redeker, J. Tague, and M. Terretta

2015 Law, expertise, and protean ideas about African migrants. In African Asylum at a Crossroads: Activism, Expert Testimony, and Refugee Rights. I. Berger, et al, eds. Pp. 1-37. Athens, OH: Ohio University Press.

Lawrance, B.N. and G.B. Ruffer

2015 Witness to the persecution? Deciphering the dialectic of expert testimony and asylum adjudication. In Adjudicating Refugee and Asylum Status: The Role of Witness, Expertise, and Testimony, B.N. Lawrance and G.B. Ruffer, eds. Pp. 122. Cambridge: Cambridge University Press.

Leach, $\mathrm{M}$.

2010 Time to put Ebola in context. Bulletin of the World Health Organization 88(7). Lewis, R.

2013 Deportable subjects: Lesbians and political asylum. Feminist Formations 25(2):174-194.

Ludwig, B.

2016 Thrust into the spotlight: Liberian refugees dealing with Ebola and other stigmas. In The Psychosocial Aspects of a Deadly Epidemic: What Ebola Has Taught Us about Holistic Healing. J. Kuriansky, ed., Pp. 149-163. Westport, CT: Praeger. Luongo, K.

2015 Allegations, evidence, and evaluation: Asylum seeking in a world of witchcraft. In African Asylum at a Crossroads. I. Berger et al, eds. Pp. 182-202. Athens, OH: Ohio University Press.

Mahajan, M.

2008 Designing epidemics: models, policy-making, and global foreknowledge in India’s AIDS epidemic. Science and Public Policy 35(8):585-596. 
Margulies, P.

1994 Asylum, intersectionality, and AIDS: Women with HIV as a persecuted social group. Georgetown Immigration Law Journal 8(4):521-556.

Mbembe, A. and J. Roitman

1995 Figures of the subject in times of crisis. Public Culture 7: 323-352

McColl, H., K. McKenzie, and K. Bhui

2008 Mental healthcare of asylum-seekers and refugees. Advances in Psychiatric Treatment 14(6):452-459.

McKinnon, S. L.

2009 Citizenship and the performance of credibility: Audiencing gender-based asylum seekers in US immigration courts. Text and Performance Quarterly, 29(3):205221.

2016 Gendered Asylum: Race and Violence in U.S. Law and Politics. UrbanaChampaign, IL: University of Illinois Press.

Millbank, J.

2009 'The ring of truth': A case study of credibility assessment in particular social group refugee determinations. International Journal of Refugee Law 21(1):1-33.

Mountz, A, R. Wright, I. Miyares, and A.J. Bailey.

2002 Lives in limbo: Temporary protected status and immigrant identities. Global Networks 2(4):335-356.

Musalo, K.

1998 Ruminations on In Re Kasinga: The decision's legacy. USC Review of Law and Women's Studies 7:35-7.

Noiriel, G. 
1991 Réfugiés et Sans-Papiers : la République Face au Droit D'asile XIXe-XXe Siècle. Paris: Calmann-Lévy.

Nunes, J.

2016 Ebola and the production of neglect in global health. Third World Quarterly 37(3):542-556.

Papastergiadis, $\mathrm{N}$.

2005 The Invasion Complex: Deep Historical Fears and Wide Open Anxieties. Willy Brandt Series Working Papers in International Migration and Ethnic Relations 2/05. School of International Migration and Ethnic Relations, Malmö University. Piot, C.

2007 Representing Africa in the Kasinga asylum case. In Transcultural Bodies: Female Genital Cutting in Global Context. Y. Hernlund and B. Shell-Duncan, eds. Pp. 224-33. New Brunswick, NJ: Rutgers University Press.

Power, S.

2014 Ebola has no greater friend than fear. Huffington Post, October 31. http://www.huffingtonpost.com/samantha-power/ebola-crisis_b_6083778.html Redeker Hepner, T.

2015 The 'asylum-advocacy nexus' in anthropological perspective: Agency, activism, and the construction of Eritrean political identities. In African Asylum at a Crossroads. I. Berger et al, eds. Pp. 225-246. Athens, OH: Ohio University Press.

Ricœur, P.

1965 Freud and philosophy: An essay on interpretation. New York: Penguin. Riles, A.

2000 The Network Inside Out. Ann Arbor, MI: University of Michigan Press. Rogers, M. 
2015 Sprinter loses family to Ebola, facing deportation back to Sierra Leone. USA Today. October 3.

[http://www.usatoday.com/story/sports/olympics/london/track/2015/10/03/sprinter -ebola-england-scotland-commonwealth-games-sierra-leone/73290732/]

Rothstein, F.

2009 Global knowledge flows: Participating in international meetings. Anthropology News 50(9):20.

Schroven, A.

2014 Ebola in Guinea: Revealing the state of the state. Hot Spots, Cultural Anthropology website, October 7. http://www.culanth.org/fieldsights/587-ebolain-guinea-revealing-the-state-of-the-state

Seghetti, L.K. Ester, and R.E. Wasem.

2015 Temporary protected status: Current immigration policy and issues. Current Politics and Economics of the United States, Canada and Mexico 17(3):429-440.

Siméant, J.

1998 La Cause des Sans Papiers. Paris: Presses de Sciences Po.

Smith, J.D.

2014 Cancer care for refugees. The Lancet Oncology 15(9): 363-e364.

Stempniak, D.D.

1999 Seeking asylum status for HIV-positive aliens based on membership in a persecuted social group: An alternative to overturning the United States' exclusion of HIV-positive aliens from immigration. Southern Illinois University Law Journal 24(1):121-136.

Stevens, J.

1999 Reproducing the State. Princeton, NJ: Princeton University Press. 
Stewart, D.

1989 The hermeneutics of suspicion. Literature and Theology 3(3):296-307.

Sweeney, J.A.

2009 Credibility, proof and refugee law. International Journal of Refugee Law 21(4):700-726.

Taylor, D.

2015 Jimmy Thoronka: Home Office rejects application to stay in UK. The Guardian,

October 1. [http://www.theguardian.com/uk-news/2015/oct/01/jimmy-thoronkahome-office-rejects-application-uk-sierra-leone]

Terretta, M.

2015 Fraudulent asylum-seeking as transnational mobilization. In African Asylum at a Crossroads. I. Berger et al, eds. Pp. 58-74. Athens, OH: Ohio University Press. Thomas, R.

2006 Assessing the credibility of asylum claims: EU and UK approaches examined. European Journal of Migration \& Law 8:79-96.

2008 Consistency in asylum adjudication: Country guidance and the asylum process in the United Kingdom. International Journal of Refugee Law 20:489-532.

Ticktin, M.

2005 Policing and humanitarianism in France: Immigration and the turn to law as state of exception. Interventions 7(3):347-368

2006 Where ethics and politics meet: the violence of humanitarianism in France. American Ethnologist 33(1):33-49.

United Kingdom Border Agency (UKBA) 
n.d. http://www.ukba.homeoffice.gov.uk/policyandlaw/guidance/coi/.

United Kingdom Home Office (UKHO)

2015 Asylum Policy Instruction: Assessing credibility and refugee status. Version 9.0, January 6 .

[https://www.gov.uk/government/uploads/system/uploads/attachment_data/file/39

7778/ASSESSING_CREDIBILITY_AND_REFUGEE_STATUS_V9_0.pdf]

United Nations High Commission for Refugees

2011 Handbook and Guidelines on Procedures and Criteria for Determining Refugee

Status [http://www.unhcr.org/refworld/docid/4f33c8d92.html]

2013 Beyond Proof: Credibility Assessment in EU Asylum Systems. Brussels, Belgium: UNHCR.

Wald, P.

2008 Contagious: Cultures, Carriers, and the Outbreak Narrative. Durham, NC: Duke University Press.

Watson-Stryker, E.

2016 Psychosocial care for Ebola patients: The response of Doctors Without Borders/Médecins Sans Frontières. In The Psychosocial Aspects of a Deadly Epidemic: What Ebola Has Taught Us about Holistic Healing. J. Kuriansky, ed., Pp. 167-174. Westport, CT: Praeger.

Weston, A.

1998 'A witness of truth': credibility findings in asylum appeals. Immigration and Nationality Law and Practice 12:87-89.

Weiss, $\mathrm{M}$.

2015 Mobilizing around a(nother) plague. PS: Political Science \& Politics 48(1):5-6. 
Wilkinson, A.

2017 Emerging disease or emerging diagnosis?: Lassa Fever and Ebola in Sierra Leone. Anthropological Quarterly 90(2): 369-397.

Wilkinson, A. and M. Leach.

2014 Briefing: Ebola - Myths, realities, and structural violence. African Affairs 109:113.

Willen, S.

2011 Do 'illegal' migrants have a right to health? Engaging ethical theory as social practice at a Tel Aviv open clinic. Medical Anthropology Quarterly 25(3):303330.

Willen, S. and J. Cook

2016 Health-related deservingness. In Handbook of Migration and Health. F. Thomas, ed. Pp 95-118. Cheltenham, UK: Edward Elgar Publishing.

Youde, J.

2015 The World Health Organization and responses to global health emergencies. PS: Political Science \& Politics 48(1):11-12.

Zeleznikow, J.

2000 Building decision support systems in discretionary legal domains. International Review of Law, Computers \& Technology 14(3):341-356. 


\section{Notes}

${ }^{1}$ UK Asylum applications increased from 4,256 in 1987 to 84,132 in 2002, before falling to 25,712 in 2005 . Applications declined temporarily to 17,916 in 2010 , but have risen each year, to 32,414 (including dependents 38,878) in 2015. (Blinder 2016).

${ }^{2}$ Convention Relating to the Status of Refugees (adopted July 28, 1951, entered into force April 22, 1954) 189 UNTS 137 (UN Refugee Convention); Protocol Relating to the Status of Refugees (adopted January 31, 1967, entered into force October 4, 1967).

${ }^{3}$ In the UK, in 2015, 64 percent of asylum applications were initially refused. A majority lodge appeals. In 2015, 35 percent of appeals were allowed (Blinder 2016).

426 I\&N Dec. 227 (BIA 2014) Matter of $M-E-V-G-$, Respondent. February 7, 2014. U.S.

Department of Justice, Executive Office for Immigration Review Board of Immigration Appeals.

5 American Psychological Association, “Managing your fear about Ebola.” Last visited August 31, 2017 <http://www.apa.org/helpcenter/ebola-fear.aspx>

${ }^{6}$ N. v. The United Kingdom, Appl. No. 26565/05, Council of Europe: European Court of Human Rights, May 27, 2008, <http://www.refworld.org/cases,ECHR,483d0d542.html>

${ }^{7}$ Buchanan 2014: "[T] $[$ here is only one trained—but semi-retired—psychiatrist serving Sierra Leone's four million people." 